\title{
INFLUENTTA TRIFLURALINEI ASUPRA DEZVOLTĂRII PLANTELOR DE SOIA ȘI IMPACTUL BACTERIILOR SIMBIOTROFE ASUPRA UNOR NEMATODE DIN GENUL DITYLENCHUS
}

\section{Todiraș Vladimir ${ }^{1}$, Lungu Angela 1, Melnic Maria ${ }^{2}$, Rusu Ștefan ${ }^{2}$, Erhan Dumitru ${ }^{2}$, Onofraș Leonid ${ }^{1}$}

2Institutul de Microbiologie și Biotehnoloie, or.Chișinău, Republica Moldova ${ }^{1}$ Institutul de Zoologie, or.Chișinău, Republica Moldova vtodiras@inobox.ru

https://doi.org/10.53937/9789975315975.63

Unele date bibliografice (Пароменская, 1990) remarcă faptul că acțiunea fitotoxică a erbicidelor triazine asupra plantelor leguminoase este însoțită de scăderea numărului de nodozități pe rădăcini, micșorarea lor în volum și micșorarea cantității de legoglobină în ele. Efectuând experiențe vegetative cu soia prin utilizarea treflanului în concentrație de 0,25 $\mathrm{mg} / \mathrm{kg} / \mathrm{sol}$ cercetătorii au stabilit că acest erbicid este foarte toxic față de sistemul rizobio-bacterian, masa brută a plantelor scade - cu 60,4\%, a rădăcinilor - cu 66,7\%, a nodozităților - cu 63,6\%, iar activitatea nitrogenazei se micșorează de 7,62 ori față de martor.

Studiind în experiențe de câmp acțiunea erbicidelor Treflan, Linuron și Prometrin asupra eficacității inoculării soiei cu bacteriile de nodozități s-a ajuns la concluzia, că utilizarea acestor erbicide ar putea fi un factor ce micșorează eficacitatea preparatelor ce au la bază bacteriile de nodozități (Пароменская и др., 1987). Cercetări de acest gen au fost efectuate și de colaboratorii laboratorului Microbiologia solului al Institutului de Microbiologie și Biotehnologie. Scopul investigațiilor la prima etapă de cercetare a fost de a stabili reacția soiei față de erbicidul Trifluralina în diverse doze de utilizare și influența lui asupra procesului de creștere și dezvoltare a plantulelor. 
Investigațiile s-au efectuat pe parcursul mai multor experiențe. În prima serie de experiențe s-a studiat influența erbicidului Trifluralina asupra capacității germinative a semințelor și dezvoltării plantulelor de soia. Concentrațiile utilizate au fost următoarele: 1, 10 și 20 mg trif./1 L apă. În altă experiență - 1, 5, 10 și 25 mg trif./1kg sol. În rezultatul investigațiilor s-a stabilit că concentrațiile de trifluralină folosite nu au avut un impact important asupra capacității germinative a semințelor. În ceea ce privește creșterea și dezvoltarea plantulelor apoi în paralel cu creșterea dozei de erbicid, lungimea rădăcinilor la soia s-a micșorat considerabil, acestea deformându-se puternic.

Pe parcursul a mai multor ani laboratorul Fitomicrobiologie (în prezent Microbiologia solului) al Institutului de Microbiologie și Biotehnologie pe principii de colaborare științifică cu Laboratorul de Parazitologie și Helmintologie al Institutului de Zoologie au studiat efectul nematocid al bacteriilor de nodozități (Rhizobium japonicum 646a, Rh. japonicum RD2, Rh. meliloti 19k, Rh. phaseoli F1) asupra speciilor de nematode din genul Ditylenchus - D. destructor și D. dipsaci. În rezultatul investigațiilor s-a stabilit că ele acționează în mod diferit asupra acestor specii de nematode. Mai active s-au dovedit a fi filtratele lichidelor culturale ale tulpinilor de bacterii din genul Rhizobium (646a și RD2). Bacteriile respective în contact cu nematodele Ditylenchus destructor și D. dipsaci au influențat distructiv asupra acestor paraziți, provocând mortalitatea de 95-98\% în timp de 24-48 ore. Alte bacterii au acționat mai slab - efectul activității tulpinii Rh. phaseoli F1 a fost de 80-90\%, iar a Rh. meliloti 19k - 0\%.

Lichidul cultural al bacteriilor Rh. japonicum RD2 (1:200, cu o expunere de 16 ore) nu exercită fitotoxicitate asupra dezvoltării plantelor de cartofi, iar în perioada de vegetație se observă acțiune de stimulare a creșterii și dezvoltării acestora: numărul de lăstari/plantă, precum și a diametrului mediu este de 2 ori mai mare, iar înălţimea- cu 13,1 cm mai mare decât la plantele din lotul martor. De asemenea, această bacterie are însușire nematocidă, care a contribuit la diminuarea intensităţii inva- 
ziei pînă la 1-5\%, ceea ce în comparaţie cu recolta obţinută de pe lotul martor (25-30\%), este cu mult mai mică.

Reieșind din datele obținute s-au făcut următoarele concluzii:

1. Trifluralina utilizată în dozele 5, 10, 20 și 25 mg/kg /sol influențează negativ asupra dezvoltării plantulelor de soia. Asupra capacității germinative a semințelor dozele indicate nu influențează semnificativ.

2. Capacitățile menționate pe care le posedă tulpina Rhizobium RD2 indică posibilitatea de a obține biopreparate complexe de stimulare a dezvoltării plantelor și nematocide pentru protecția plantelor (de cartofi) contra nematodelor.

Studiile au fost realizate în cadrul proiectului instituțional fundamental 15.817.02.12F. 